\title{
The Dilemma Monologue in The Love Song of J. Alfred Prufrock
}

\section{Songmeng Liu}

School of Humanities, Tiangong University, Tianjin, China

Email: 78921389@qq.com

How to cite this paper: Liu, S.M. (2021) The Dilemma Monologue in The Love Song of J. Alfred Prufrock. Open Access Library Journal, 8: e7053.

https://doi.org/10.4236/oalib.1107053

Received: November 30, 2020

Accepted: January 11, 2021

Published: January 14, 2021

Copyright $\odot 2021$ by author(s) and Open Access Library Inc.

This work is licensed under the Creative Commons Attribution International License (CC BY 4.0).

http://creativecommons.org/licenses/by/4.0/

\begin{abstract}
Prufrock has always been known as an image of cautious, well-educated and moody urban man created from T. S. Eliot's distinguished poem The Love Song of J. Alfred Prufrock. In his monologue, he uses clever expressions to tell the audience what has been haunting him for so long that it becomes his dilemma. In this paper, it explains that Prufrock's dilemma does not come entirely from the suppression of his desire or libido, but much more from the imbalance between the ideal world and the real world.
\end{abstract}

\section{Subject Areas}

Literature

\section{Keywords}

Dilemma, Prufrock, Eliot, Monologue

\section{Introduction}

The Love Song of J. Alfred Prufrock, commonly known as "Prufrock" is the early masterpiece written by American-born English poet T. S. Eliot. It was first published in the June 1915 issue of Poetry: A Magazine of Verse and later printed as part of a twelve-poem pamphlet titled Prufrock and Other Observations in 1917. Considered one of the $20^{\text {th }}$ century's major poets, Eliot attracted widespread attention for his poem "Prufrock" which was seen as a masterpiece of the modernist movement.

At the beginning of the $20^{\text {th }}$ century, European and American life had undergone significant and irrevocable changes. Industrialization and new technologies had transformed society and workforce. And also the First World War made the social situation more turbulent where the spiritual world of modern urbanite is 
on the verge of collapse and the whole western world is in a state of disorder. Eliot also observed that "the consciousness of confusion was particularly pronounced in the early 20th century" [1]. The Love Song of J. Alfred was created in such historical context. Eliot's friend, the poet Conrad Aiken once said that Prufrock was about a distressed and anxious freak [2]. The hero of the poem, J. Alfred Prufrock, a middle-aged intellectual living in a modern city who was timid, sensitive and irresolute told his bitter dilemma to his silent audience in his monologue.

This paper attempts to focus on the discussion of Prufrock's dilemma from two aspects. First, Prufrock's desire or libido was not able to be satisfied in light of the deficiency of masculinity and women' strong position. Second, Prufrock's ideal society cannot be balanced with the society he is living in. He was confined by the real world and had no way to change and flee. Therefore, it was his dilemma that made him could not live in harmony with the real world and then led to him spiritually paralyzed and alienated. Prufrock as a typical figure alluded more or less to the spiritual situation of early modern westerners. As Cleanth Brook pointed out, "Prufrock" was not about the dilemma of individuals and individual cities, but about the dilemma of an era and Western civilization [3].

\section{Nowhere to Place Libido}

The beginning of the poem showed the speaker, J. Alfred Prufrock intended to go somewhere maybe be a salon or a party and visit someone. But actually Prufrock did not go out until the end. He just stayed where he was. All of these were his fantasy through his monologue. He seemed to need someone to confess his trouble and struggle by his extraordinary metaphors and allusions.

\subsection{The Floating Libido}

According to the definition from Online Etymology Dictionary, the word "libido" is from Latin word "lubido" which means psychic drive or energy, usually associated with sexual instinct and sensual passion and lust. It was used in 1909 in A.A. Brill's translation of Freud's "Selected Papers on Hysteria" and it was Freud's use of the term that led to its popularity. Freud coined a new meaning to the term that people were fundamentally motivated to do things by libido. In this poem, Prufrock was tantalized by some unconscious behavior of those exquisite ladies. For example, Prufrock observed their arms "that are braceleted and white and bare. Is it perfume from a dress that makes me digress" [4]. It was distinct from above descriptions that what aroused his desire was the sensuous shock, the soft white arms of the women and the faint scent in the air. So in this respect, the "love song" was not involved love, an erotic fantasy at best. It was Prufrock's libido that made him have a maggot in his head. In the fall of 1959, Eliot explained to a reporter that "There was probably not much love in the life of J. Alfred Prufrock" [2]. Maybe Prufrock himself knew that his initiative only 
got women's cold rejection and merciless ridicule. But actually he was no more affectionate than they are. He wooed only by the lure of white arms, motivated purely by his libido.

\subsection{The Deficiency of Masculinity}

Prufrock was not particularly distinctive in his physical appearance. His was so anxious about making the wrong choice that he could not barely make any decisions at all. He did not dare to approach to those elegant ladies in the room because of his slight hair and thin body. He truly cared about what those ladies thought and was afraid of their judgements. He imagined what they would say like "how his hair is growing thin!" and "but how his arms and legs are thin!" So he did not go further, just staying at a corner and wallowed into self-pity. The image of ladies talking casually of Michelangelo added stark contrast with the figure of Prufrock. Michelangelo, one of the three Renaissance heroes, was hailed by Roman Roland as "the noble peak of the Renaissance". Michelangelo's art was famous for the beauty of heroism, and the figures in his creation was robust and handsome. In his creations, whether it is David, Moses or Adam of Genesis, was distinguished by strong masculinity in sharp contrast to Prufrock's baldness, thin arms and fine legs.

Hair also has a rich meaning in western culture. In the bible, hair is a symbol of male strength and courage. Samson, the biblical Israelite strongman, tore a lion as a lamb with his bare hands. The source of his magical power was his hair. Later, he was seduced by the prostitute Dalilah and shaved off his hair. Then Samson lost his power immediately and could not get revenge until his hair grew back. Without lush hair and strong limbs, Prufrock could be seen as a frail lamb in others' eyes. British social and cultural anthropologist Edmund Leach thinks that hair has a symbolic meaning from the perspective of anthropology and believes that hair contains sexual associations for example, head represents the male genitalia and the hair represents semen. That is to say Prufrock' baldness was a sign of his diminished sexual performance and deficiency of his masculinity.

\subsection{Weak Position among Women}

The poem originally had a subtitle which was Prufrock among the Women. Apparently Eliot's intending to set such a subtitle highlights the disparity in power between Prufrock as an individual and women as a group, which led to a tension between men and women [5]. The women seemingly formed a powerful siege against Prufrock. For example, Prufrock has already known how those women in the room look him up and down and judge him. He felt like their eyes "fix you in a formulated phrase, and when I am formulated, sprawling on a pin" [4]. Sprawling means someone sit, lie or fall with one's arms and legs spread out in an ungainly way. Here Prufrock was fixed on the wall by women's eyes as sharp as a pin. This was obviously what feelings Prufrock experienced under such con- 
dition-he was so helpless, fluttered and indisposed that he could hardly move like a dying insect. These women were arbiters of Prufrock's fate whose every move could be the death blow to Prufrock.

Besides the feeling of being nailed to the wall, the poem repeatedly showed women in and out of the room, talking of Michelangelo, as if the women were the main characters in the room, delighting themselves with scenes of refinement and the cynosure of all eyes. While Prufrock, he was not so much a participant as a bystander on the edge of the party, always in a neglected position watching the group of women who blended very well into their environment, laughing and having fun. It is worth noting that the communication in the social gathering was all from women. All these will remind people of what Foucault said, that is "Power is saying." This can be said to be mandatory, through some definition and operation, thus these women in the room had the power to dominate. As the main body, they defined and judged whether Prufrock was fit to attend the party or whether he was qualified to pursue his libido.

In fact, except the ladies of the social gathering, other images about women in this poem also appeared in a way that cannot be taken lightly. For instance, Prufrock still mentioned a biblical allusion to John the Baptize in which John, the prophet was died of a woman's provocation eventually. Although John was loved and respected by his people, his power still can hardly compete with the daughter of Herodias. And also the image of mermaids, whether in ancient Greek mythology or in this poem, mermaids were all very forceful, bright and lusty rather than weak and tender.

According to what has been said above, one of severe dilemmas of the hero.

Prufrock was the unbalance between his primitive desire and his own weakness. The weakness absolutely stemmed from his masculinity and his position comparing with women.

\section{The Unbalance between Ideal and Real World}

The poet Eliot once wrote in his Hamlet and His Problems that "The only way of expressing emotion in the form of art is by finding an 'objective correlative'; in other words, a set of objects, a situation, a chain of events, which shall be the formula of that particular emotion." In this poem he also used the objective correlative to express Prufrock's ideal world and real world. The unbalance between ideal and real world is the key to Prufrock's dilemma.

\subsection{The Ideal World Prufrock Yearns for}

Prufrock as a depressed intellectual has his own paradise where he has been longing for-a pure and free place where he can enjoy and relax without coldness and solitude. In this poem, he placed his hope for a wonderful life on the image of mermaid and sea. In the last eight lines of the poem, he fancied "I have heard the mermaids singing, each to each. I do not think they will sing to me" [4]. Mermaid is a very frequent image in western culture which has rich mean- 
ings such as sincerity, kindness and fairness. Mermaids are sometimes equated with the siren of Greek mythology especially the Odyssey by Homer. It is said that mermaids had no souls and they were seen as charming and heady creature whose enchanting singing would attract attention of the soon-to-be-shipwrecked sailors and then once they were lured they will be killed by femmes fatales. But here Prufrock said they would not sing to him. That is to say Prufrock wasn't the one the mermaids wanted to hurt and kill. Because they were of one kind which possessed two kinds of different things. The mermaids were half human body and half fish while Prufrock's mixture was his ideal world and real world, his libido and procrastination. No matter the mermaids or Prufrock, they were all confined to the junction with themselves and can never transcend the boundary. Some American researchers believed that mermaids were part of a group of apes that entered the sea during the evolution of the hominid into humans. But in the long evolutionary years, human beings forgot them and these mermaids became a legend. So to some extent these mermaids were nothing but alienated from human beings and live in another world. The same is true of Prufrock who alienated from the social gathering, the real world he was living in intentionally or not.

In the mermaid's world, Prufrock was very relaxed and comfortable, where "the white hair of the waves" seemly gave him some comfort so that he was no longer worried about his aging and weakness. These sea-girls were extremely different with those ladies in social gathering. Comparing to the ladies who come and go, the sea-girls were "riding seaward on the waves" [4]. There is no doubting that how free and broad the latter's world is and cannot help but think of a line in a Chinese poem: Hop like a fish in the sea, fly like a bird across the sky (海阔凭鱼跃, 天高任鸟飞). These mermaids were pure, lively and more natural and sincere whose life could be seen as a symbol of Prufrock's dream world. A world where everyone can sincerely sing and interaction without fudge, hypocrisy and pretense. They "lingered in the chambers of the sea by sea-girls wreathed with seaweed red and brown" [4]. The word linger implied Prufrock did not want to leave his ideal world and went back to his original world. The poem ended with the sea as a chamber where was decorated by mermaids with red and brown seaweed. It is widely acknowledged that sea is a symbol of gestation and rebirth. The Prufrock slept in this palace just as the unborn baby in the mother's womb, absorbing the mother's nutrition and preparing to be born into a new world. The sea was the beginning of a new life, symbolizing Prufrock's desire for escaping his original world and rebirth.

\subsection{The Real World Prufrock Lives}

In this poem, Eliot added an epigraph from Dante's Inferno [4]:

"S'io credesse che mia risposta fosse

A persona che mai tornasse al mondo,

Questa fiamma staria senza piu scosse. 
Ma perciocche giammai di questo fondo

Non torno vivo alcun, s'i'odo il vero,

Senza tema d'infamia ti rispondo."

The epigraph translates into English as: "If I thought that my reply would be to someone who would ever return to earth, this flame would remain without further movement; but as no one has ever returned alive from this gulf, if what I hear is true, I can answer you with no fear of infamy" [6]. These lines were spoken by Guido da Montefeltro, a man condemned to hell who promises to tell the Inferno's speaker about the sins that have landed him in Hell. Regarding to the Hell Guido was imprisoned was the eighth circle called Malebolge (evil ditches). Dorothy L. Sayers writes that the Malebolge is "the image of the city in corruption: the progress disintegration of every social relationship, personal and public" [7]. Like Guido, Prufrock seemed to want to confess his audience something that could not be known by others maybe his sins and explained how he has been confined to a hellish, modern urban landscape.

In the beginning of the poem, the speaker described the urban landscape with some images to convey his feelings and impressions. For example, the speaker said the evening was like "a patient etherized upon a table" [4]. This image can well illustrate that in the speaker's eyes, the city where he was living even the country and the world have taken on a morbid appearance without any vitality or energy like a weak and unconscious patient waiting for surgery. Moreover, the speaker mentioned the yellow fog which is described as "rubbing", "licking", and "lingering" along the windows of houses and among the city. It seemed like a giant monster who is eager to swallow everything and his shadow pervades everywhere. It is quite clear that the yellow color of the fog is thus symbolic of the condition of modern life, which is shaped by technology and industrial production. The whole city was severely polluted by the products of mechanical civilization and the destroy of the ecological homeland of westerners is truly the first step toward chaos and disorder.

With the rapid development of capitalism, even if enjoying great material abundance, the whole western world was also experiencing great pain brought by the disordered development. People were forced to be drown into a whirlpool of the pursuit of interests. This trend in the economic society also directly led to the chaos of the spiritual world. Material prosperity did not bring happiness; on the contrary, a deep sense of emptiness takes hold. The yellow fog meant the intersection of day and night as a state that is neither rational nor irrational giving the poem a more abstract but still pervasive sense of unease, as if the city was colored by the seediness, corruption, and darkness with which the speaker characterized the world around him like the real hell where Guido was confined. It also represented the inner world of Prufrock: dim, lazy, anchorless and disordered. Eliot once said in an interview that he wanted express a state of disorder of western world. So it goes without saying that Prufrock as the spokesman of this state of "an ambiguous world between life and death" [8]. 
In western culture, yellow still has a meaning of timidity such as "yellow streak" and "yellow-livered". Hence it is reasonable that the character of Prufrock had some similarities with the city where was covered by the yellow fog, or maybe Prufrock was influenced by the atmosphere and condition of the city. Everyone was more or less unhealthy mentally and this unhealthy was mainly embodied on their interaction. They could not interact with others especially the hero, Prufrock. Even though they had a conversation, it was empty and tongue-in-cheek just like the coming and going arty ladies who could only talk in generalities about art. Looking back the whole poem, he was actually trapped in a circle of self-expression, sealing himself in a literal "real" space and eliminating the possibility of interacting with others to achieve real alienation. He said that he should have been "a pair of ragged claws, scuttling across the floors of the sea" [4]. The image of claws might have come from Laforgue whose claws also often complained of having a pair of tentacles which is so sensitive that feel too much [9]. Prufrock was so sensitive and discreet to the world around him that any minor details could hurt him. He felt how shallow and boring the world was. He wanted to take some meaningful action but lacked energy and brave. The only thing he could do was fancy and dream. Therefore, Prufrock imagined an arcadia and yearned for rebirth because of the dissatisfaction and despair of reality, which led him to believe that the world was a wasteland of death, without hope or change. After all, this was a dream rather than reality. That was why “Till human voices wake us, and we drown" [4].

\section{Conclusions}

Through reading and analyzing The Love Song of J. Alfred Prufrock, it can be found that there are two different kinds of desires existing in the hero Prufrock himself: the libido in secular world and something more spiritual in his ideal world. However unfortunately, either way, it won't happen to him, thus becoming his dilemmas where he knows everything but never act on it or he cannot.

Prufrock was foreign to the society in which he lives in, wandering on the fringe of private and solitary life. The true reason that led to such an imbalanced condition was the collapse of westerners' spiritual and ecological homes. Especially the barren of their spiritual home broke the last border of their hearts. In a word, the dilemma of Prufrock was definitely not an individual phenomenon but reflected the overall spiritual disillusionment and paralysis of westerners in the early $20^{\text {th }}$ century world. And The Love Song of J. Alfred Prufrock was in fact a ruthless song or monologue in which there was no pure love at all but a kind of helplessness for human feeling, an irony on the spiritual crisis of modern Westerners, and a dilemma of the westerners represented by Prufrock.

\section{Conflicts of Interest}

The author declares no conflicts of interest regarding the publication of this paper. 


\section{References}

[1] Damrosch, D., et al. (2003) The Longman Anthology of British Literature. 2nd Edition, Addison-Wesley Educational Publishers Inc., Boston.

[2] Ackroyd, P. (1984) T. S. Eliot: A Life. Simon \& Schuster Inc., New York.

[3] Brooks, C. (1988) Teaching the Love Song of J. Alfred Prufrock. Jewel Spears Brooker. Approaches to Teaching Eliot's Poetry and Plays. The Modern Language Association of America, New York, 78-87.

[4] Eliot, T.S. (2009) Selected Poems of T. S. Eliot. Faber and Faber Ltd., London.

[5] 周亭亭.社会转型与身体焦虑——评《普鲁弗洛克的情歌》 [J]. 解放军外国语学院 学报, 2013(5): 103-108. (In Chinese)

[6] Alighieri, D. (2011) The Inferno (Hollander, R., Hollander, J., Eds.) Princeton Dante Project, Princeton.

[7] Alighieri, D. (1949) Dante: The Divine Comedy, Hell (Sayers, D.L., Ed.). Penguin Books, London.

[8] Wang, Q. (2016) On the Significant Issues in "The Love Song of J. Alfred Prufrock". Journal of Sichuan Normal University (Social Sciences Edition), No. 5, 122-130.

[9] 张剑. 充满喜剧效果的悲剧——分析艾略特《J. 阿尔弗莱德.普鲁弗洛克的情歌》 [J]. 外国文学评论, 1997(16): 77-81. (In Chinese) 